\title{
Measuring the Quality of Life Felda Residents in Iskandar Malaysia Based on Perception of Quality of Life Index
}

\author{
Wan Zahari Wan Yusoff, Ezhwan Nur Arshad \\ Faculty of Technology Management and Business \\ University Tun Hussein Onn \\ Malaysia \\ zahari@uthm.edu.my
}

\begin{abstract}
Quality of life is a change in the society from a state that is considered unsatisfactory to a better condition which includes not only economic development but also involves various aspects such as social, psychological, cultural, political and environmental. The success of a placement can be measured by the improvement in the quality of life of the local residents. Iskandar Malaysia (IM) is a rapidly growing and developing area of which they are expected to contribute to the lives betterment of people in the economy and in the surrounding area as stated in the Comprehensive Development Plan for South Johor Economic Region. The question arises to what extent the IM development projects beneficial to the survival of the residents in the area as well to help improve the quality of life of the local residents in line with the current rapid development being carried out. Therefore, the main objective of this study is to determine the quality of life of Felda residents in Iskandar Malaysia using quality of life perception index. The research focused on the Felda population in Iskandar Malaysia based on the justification that they are the group of people who receive the most significant impact on the development of IM in the process of land acquisition and loss of shelter and habitat for future employment with the expectations of receiving a better life. IM perception Quality of life measurement model is determined based on the Malaysian Quality of Life Index. In addition, the measurement of quality of life through perception model was constructed to solicit comments from the locals. The research methodology is through the collection of primary data and secondary data from surveys and interviews and collecting data from the relevant agencies. The data were analyzed and the results showed that the quality of life of Felda residents in IM at moderate levels. Only two components are achieved at the satisfactory level namely transportation and housing. This study hopes to benefit the related parties who involve in the policy making in reviewing the existing policy towards a better development which will subsequently increase the level of quality of life of the local and native residents in IM.
\end{abstract}

\section{Indexing terms/Keywords}

Quality of Life, Index Perception of Quality of Life, Iskandar Malaysia

\section{Academic Discipline And Sub-Disciplines}

Social Science; Economic Growth, Development and Planning

\section{SUBJECT CLASSIFICATION}

Quality of Life

TYPE (METHOD/APPROACH)

Survey and Interview

\section{Council for Innovative Research}

Peer Review Research Publishing System

Journal: International Journal of Management \& Information Technology

Vol. 6, No. 3

editor@cirworld.com

www.cirworld.com, member.cirworld.com 


\section{INTRODUCTION}

Quality of life of a community has been frequently discussed by various parties, not only in Malaysia but also globally. Measurement of quality of life of a community is not only important for policy-makers, economists or academics but also very important to the community itself (Hancock et al, 1999). National University of Singapore (2000) states that the study of quality of life is important in order to know the requirements or needs of the community in a particular place. This study shows that the quality of life in the local community particularly in the aspect such as clean water supply, public safety, education facilities, facilities and more. The success of a placement can be measured by continuous improvement in the quality of life.

Quality of life is the dream of every human being on this earth. Most people consider wanting to achieve a better quality of life, better career, better social life and a better living environment. Quality of life is a dynamic element that is in line with the changing of times and modernization and development of a community. To achieve the quality of life is not an easy matter as it requires guidance and track. Quality of life is a change in the society and the community life systems from a condition that is considered unsatisfactory to a better condition. It includes not only economic development but also various other aspects that cannot be separated such as social, psychological, cultural, political, environmental and other aspects.

Malaysian Budget (Budget) Act 2011 provides as much as RM850 million for corridor and regional development, it includes Iskandar Malaysia, Northern Corridor Regional Economics, East Coast Economic Region, Sarawak Corridor of Renewable Energy and Sabah Development Corridor.

In the case of Iskandar Malaysia development, it has received strong encouragement by the government through the allocation of RM339 million, which is the highest amount compared to the allocation given to the development corridor in other regions. This indicates that the government perceived Iskandar Malaysia as having a high potential to boost the economic growth and indirectly will improve the quality of life in Iskandar Malaysia. Iskandar Malaysia has recorded a tota of committed investment of RM59 billion as of February 2010 with a real investment value of $38 \%$. Committed investments were in manufacturing, real estate, utilities, tourism and logistics.

Thus, this research aims to examine the change and impact of quality of life of the native people who are inhabiting in the involved development area. Initially, the development in Iskandar Malaysia involves cases such as land acquisition, the risk of environmental pollution, the risk of loss of livelihood, including agriculture or fishery activities with the hope that the development of Iskandar Malaysia will create a better quality of life for local residents as well as in the surrounding areas by providing the opportunity for the local people to engage in the business activities and a better job creation.

\section{THE ISSUES}

Iskandar Malaysia is expected to attract investments from within and outside the country worth more than RM50 billion. Some investors come from the immediate neighboring countries, namely Singapore, as well as from Middle Eastern countries such as Saudi Arabia, Iran and Kuwait. In August 2007, a program organized by the Malaysian Business Council - China was held to attract more potential investors from China, Japan and Korea to invest in Iskandar Malaysia (IRDA, 2007). According to the Khazanah National (2006) Comprehensive report Development Plan for South Johore Economic Region, one of the core frameworks for the physical development of Iskandar Malaysia is to improve the quality of life of the local residents. According to the justification provided in the report, quality of life is defined as being 'economically healthy' and having job opportunities in various fields that to be widely offered to the locals. The question is to what extent the development of Iskandar Malaysia, will improve the quality of life of local communities particularly the Felda community after five (5) years' development of the Iskandar Malaysia economic corridor development.

From the literature review conducted, no studies have been conducted to evaluate the quality of life of the community in Iskandar Malaysia since the development project was implemented in the year 2007 till present. As such, a comprehensive study should be undertaken to find out the impact of the development of Iskandar Malaysia's on the quality of life of the community in the region particularly the Felda community.

\section{METHODOLOGY}

This study focuses on the Felda's population that involved in the development of Iskandar Malaysia with justification that the development is to improve the quality of life of the local residents being Felda population is one of the main groups in the development of Iskandar Malaysia. Figure 1 shows the 4 Felda settlement area in Iskandar Malaysia which are, Felda Ulu Tebrau, Felda Taib Andak, Felda Bukit Batu and Felda Cahaya Baru. 


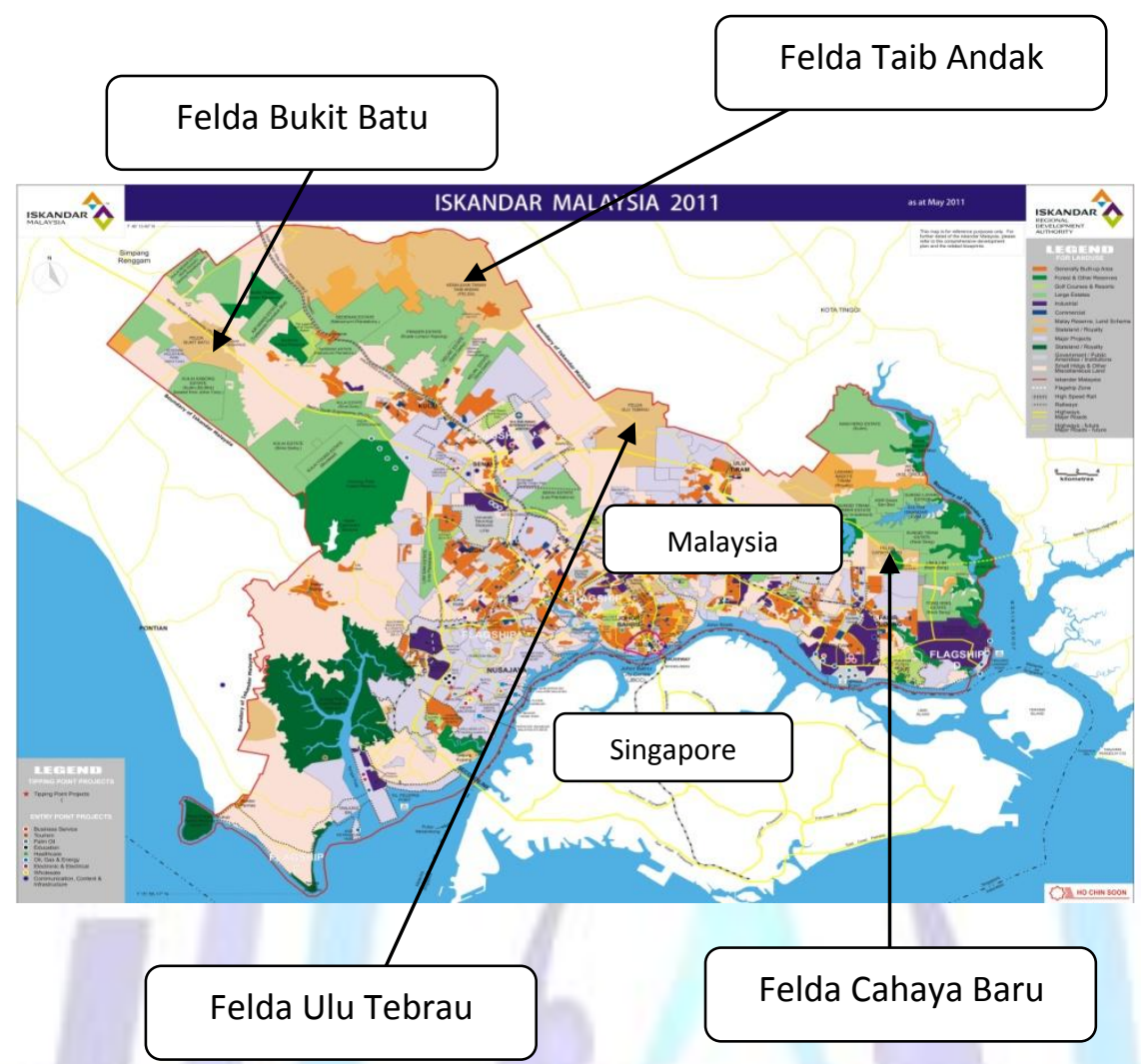

Figure 1: Location of Felda Settlements in Iskandar Malaysia Source: IRDA, 2011

Several factors have been identified prompting to focus on Felda settlements such as land acquisition for development purposes, the migration process and compensation, as well as the risk of loss of livelihoods and hopes of getting better jobs in the future. This study is considered as a social impact study on the community resulted from the implementation of Iskandar Malaysia development. Although the development of Iskandar has yet to be completed, but studies in the early stages are very important to observe the social impact. Any shortcomings whether in the planning or execution of the direction can be corrected if there is a will. Detailed information about Felda in Iskandar Malaysia development region is shown in Table 1.

Table 1: Felda Settlement Name, Area \& Number of Settler and Households

\begin{tabular}{|c|l|c|c|c|}
\hline Number & FELDA Settlements Area & Area (Hectare) & Number of Settler & Number of households \\
\hline 1 & Taib Andak & $2,901.82$ & 620 & 3100 \\
\hline 2 & Bukit Batu & $1,119.98$ & 292 & 1460 \\
\hline 3 & Ulu Tebrau & $2,680.65$ & 669 & 3345 \\
\hline 4 & Cahaya Baru & 148.27 & 96 & 480 \\
\hline & Total & $6,850.72$ & 1,677 & 8,385 \\
\hline
\end{tabular}

\section{Felda Population Profile}

The main activity in this area is oil palm and rubber plantations where Felda Bukit Baru was planted with rubber and was opened in 1969. While others, namely Felda Taib Andak, Felda Ulu Tebrau and Felda Cahaya Baru were planted with oil palm respectively opened in 1960, 1968 and 1967 (Regional Felda Johor Bahru, 2010).

\section{Population and sampling}

The population of the study is the local residents which are the Felda population in the area of Iskandar Malaysia development with a sample size of 400 people. A total of 600 questionnaires were distributed in the study area to get feedback on the perception of their quality of life. Part A of the instrument of the study is about demographics. While, Part $B$ is specifically designed for collecting the information regarding the quality of lives and perceptions as well as their expectations of their lives in the Iskandar Malaysia development corridor. The survey instrument consists of semi- 
structured questionnaires and guidance questions for interview in order to get more information about the subject under discussion.

\section{Component and Perception of Quality of Life Indicators}

In this study, a total of 12 components were used in assessing the quality of life. These components are based on the perception of quality of life assessment framework adapted from the Economic Planning unit of Malaysia (2004). The components used are as follows:

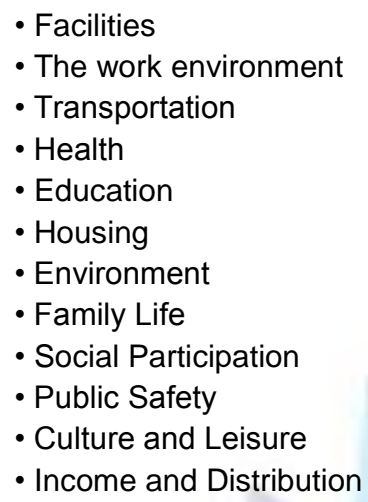

Source: The 12 Components of Quality of Life Perception of the Economic Planning Unit of Malaysia (2004)

Of the 12 components, it is itemized into 66 elements to take into account various aspects of quality of life measurements, as shown in Table 9.

\section{Measurement of Perceived Quality of Life Index}

The feedback from surveys received were evaluated and measured by a scale of the perception of quality of life index in

Table 2

Table 2: The Scale of Index Perception Quality of Life

\begin{tabular}{|c|c|l|}
\hline Scala & \multicolumn{1}{|c|}{ Definition } & \multicolumn{1}{c|}{ Explanation } \\
\hline 1 & Very Poor / Very Not Sufficient & $\begin{array}{l}\text { Respondents felt their quality of life is not good at most } \\
\text { levels }\end{array}$ \\
\hline 2 & Unsatisfied / Not Sufficient & Respondents felt their quality of life at the level of bad. \\
\hline 3 & Moderate & Respondents felt their quality of life at a moderate level. \\
\hline 4 & Satisfied / Adequate & Respondents felt their quality of life in good level. \\
\hline 5 & Very Satisfied / Very Adequate & $\begin{array}{l}\text { Respondents felt their quality of life improved in most } \\
\text { levels. }\end{array}$ \\
\hline
\end{tabular}

Source: Adapted from Unit Perancang Ekonomi Malaysia, 2002

Next, after obtaining scores for each indicator, the values of each indicator score are classified according to the percentage that represents the level of quality of life as follows:

Table 3: The Scale for Score level of Index Perception of Quality of Life

\begin{tabular}{|c|c|c|}
\hline Score & Level & Explanation \\
\hline$<20 \%$ & 1 & Extremely Not Satisfied \\
\hline $20 \%-40 \%$ & 2 & Not Satisfied \\
\hline $41 \%-60 \%$ & 3 & Moderate \\
\hline $61 \%-80 \%$ & 4 & Good \\
\hline$>80 \%$ & 5 & Best \\
\hline
\end{tabular}




\section{OVERVIEW OF STUDY ON QUALITY OF LIFE}

The studies on the quality of life began in the early 1970s where it only takes into account economic factors in social welfare measure (Birtnbacher, 1999). The concept of quality of life with more in-depth was reviewed by the physicians in the era of the 1980s that focused on indicators of patient health through their daily lives. And now a study on quality of life has steadily grown and has attracted many researchers, particularly social science researchers as awareness of the importance of knowledge of the concept of quality of life plays a big part in the formation of social policy (Mahadzirah et al, 2008).

Discussion on the quality of life is divided into three (3) main things from a scientific perspective of medical science, economic science and social science (Cummins, 2005). In medical science perspective on the quality of life, the study focused on patients' health improvements associated with better quality of life. For example a study in France indicates that $70 \%$ of mothers giving birth to son experienced lower quality of life scores compared to mothers who gave birth to daughter because the mother who gave birth to son over under pressure from the mother who gave birth to a daughter. Hence with the availability of this kind of research has produced important information to medical policy makers in which the actions to be implemented is adding a comprehensive treatment towards the mother who gave birth to a son in order to overcome the problem of stress.

Understanding the quality of life has many definitions produced by the researchers. According to Haryati (2012), quality of life is a very difficult concept to define. This is because that it is associated with many other concepts to bring a variety of other purposes as well. Zapf (1987), Noll (1999) and Sen (1987) defined Quality of life as a multidimensional concept that includes components that can be measured and cannot be measured, objective and subjective, the welfare of individuals and community groups aimed at a better well-being. Quality of life is also associated with an individual's perception of their life (Laily et al, 2002). General quality of life can be defined as excellence in human life that leads to the well-being of society and it can be increased from time to time in line with the significant efforts in human development in a country (Azemi,2006).

Malaysian Quality of Life Index Report (1999) defines quality of life in a more specific spectrum which is to include personal development, healthy lifestyles, access and freedom to acquire knowledge, standard of living beyond the basic needs of individuals and their psychological needs, to achieve the level of social welfare comparable with national aspirations. The concepts and definitions given involved the two dimensions of quality of life, namely the objective dimension and the subjective dimension. The concept of subjective dimension quality of life is associated with satisfaction with a certain conditions relating to the factors that affect their lives. The concept of the objective quality of life means a certain level of achievement in terms of the economic needs of life, social, physical, environmental and others.

Quality of life is the idea of the perfection of life. Definition of quality of life according to the Human Development Report (1999) is a condition of life that emerges from the interaction between economic factors, social, physical and environmental influence on the development of society and human life. Ferran 's (1990) gives the impression that the quality of life has a number of concepts or issues can be identified and divided into five categories. These categories focus on ( $\mathrm{i}$ ) the ability to live a normal life , ( ii) the joy or satisfaction, ( iii ) to achieve the objectives, ( iv ) the ability to lead to a more useful social life and $(v)$ the ability of physically and mentally.

According to the World Health Organization ( 1997), quality of life is defined as individual perception of their position in the context of the culture of life and the system in which it is closely related to the goals, expectations, and load level . Lehman (1983) sees the quality of life as the sense of the best experiences suffered by individuals under the influence of their life . According to Bigelow \& Brodsky (1982), quality of life is the dividing point where it unites all factors in life where we will find that there are limitations and advantages in desire and satisfaction.

Renwick (2006) stated well-being is something that makes a person feel fun, happy and feels their life are meaningful. Mohammed Fadhil (2003) also describes the well-being of life in fact is an attempt to solve the problem and improve the quality of human life to be in living a safe, healthy and comfortable physically, socially and psychologically.

Siti Fatimah (2006 ) explains the concept of well-being or quality of life is not simply measured by material values just like home ownership, vehicle, high level of education, but it also covers aspects of a material that do not like the feeling of love, warmth, between individual compassion and always felt relieved. This assertion is supported by Leplege \& Hunt (1997) that describe the quality of life is a descriptive term that refers to the human emotional, social and physical health and their ability to function in the ordinary tasks of life.

Schmandt and Bloomberg (1969) argued the meaning of life from other perspectives that involving the whole country including individual behavior, development, resources like or do not like and many more. In short, life is changing everything and every character, whether it involves death or life. Life also shows every living thing and also the lives and properties of the environment. Among the most important aspects in providing quality of life for people in particular consists of four things: political, economic, social and education (Szalai \& Andrews, 1980). 
In summary, the quality of life encompasses a broad understanding and interpretation of the various groups who have different backgrounds. Quality of life reflects an individual's life, the good life show good quality of life, and vice versa. Nik Fuad (2007) also considers the good life is synonymous with the term of quality of life. The fact that each individual expects a good life, therefore, this study aims to evaluate the quality of life of the local population in line with the development agenda to improve the quality of the lives of local residents as expected.

\section{Measurement of Quality of Life}

Formation of quality of life measurement methods is a challenge for all researchers since the measurement criteria of quality of life were multi-dimensional and complex to measure. Following this problem all researchers have used different methods and their approaches in reviewing the quality of life in accordance with the ultimate goal of the researchers. The theory of quality of life is a theory that cannot be expressed and measured directly. Therefore, the measurement depends on variable factors relevant to the requirements of the study (Mahadzirah et al, 2008).

TAC Subcommittee on social Issues (2004) has formed three main sectors of living that affect the quality of life of a society, namely the social element, economic element and environment element. This view is further reinforced by Mahadzirah et al (2008), which stated that, there are three (3) main areas in measuring the quality of life precisely in social, economic and environmental areas. This shows that in measuring the quality of life, it must be consists of 3 key areas as shown in Figure 2.

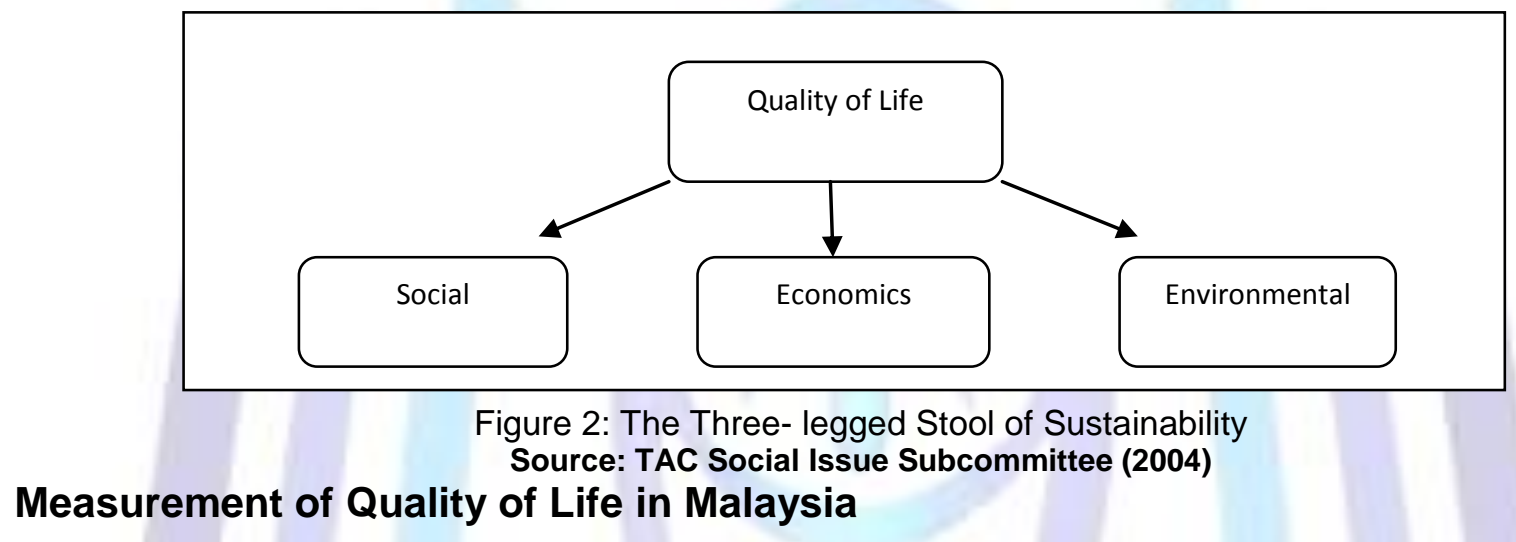

Malaysia's Economic Planning Unit in 2002 has conducted a study of the perception of quality of life in six selected cities in Malaysia namely, Ipoh, Johor Bahru, Kota Kinabalu, Kuala Lumpur, Kuantan and Kuching. A total of 11 fields with 61 elements were studied. The results of the study found that $61.7 \%$ of respondents are satisfied with their quality of life up to date with the infrastructure field $83.3 \%$ recorded the highest satisfaction and the lowest are culture and leisure at $38.8 \%$.

\section{The concept of Quality of Life in Iskandar Malaysia}

The development of Iskandar Malaysia aims to improve the quality of life of the local people and at the same time improving the economic environment. The prosperity resulting from the development of Iskandar Malaysia hopes to raise the living standard and quality of life of the local residents as well as residents from neighboring country including Singapore. As stated in the Comprehensive Development Plan (National Treasury, 2006), one of the core principles of the physical development framework is to improve the residents' quality of life through the strategic investment incentives for foreign and local investors. Through the involvement of foreign investors and foreign capital, it is expected to increase the employment and business opportunities to the locals. In this context, justification and definition of quality of life that given is "Economically Healthy" and provides job opportunities in various fields widely offered to local residents and surrounding areas. This principle is the basic and fundamental ground for forming the framework and models in measuring the quality of life of Iskandar Malaysia.

\section{RESULTS AND DISCUSSION}

These results are based on the analysis of the feedback on primary data given by 400 respondents about their perceptions of quality of life. This is based on 12 components and 66 elements of the quality of life perceptions framework (State Economic Planning Unit, Malaysia 2002).

\section{Background of Respondents}

Tables 4 to Table 7 show the demographic of the respondents. The analysis showed that the majority of respondents living in Felda in Iskandar Malaysia are aged 51 years and above. A total of 58\% of respondents aged $51-60$ years, 39\% aged 61 years and above and only 3\% are aged between 41-50 years. In terms of placement, half of the respondents of the resident began occupying in year 1960-1969 and the other half is in $1970-1979$. 


\begin{tabular}{|c|c|c|c|c|}
\hline \multicolumn{3}{|c|}{ Table 4: Age Group of Felda Settlements } & \multicolumn{2}{|c|}{$\begin{array}{l}\text { Table 5: Years Start Being Settlers in Felda in } \\
\text { Iskandar Malaysia }\end{array}$} \\
\hline \multirow[t]{2}{*}{ Age Level } & Percentage & & & \\
\hline & & & $\underline{\text { Year }}$ & Percentage \\
\hline \multirow[t]{2}{*}{$41-50$} & $3 \%$ & & & \\
\hline & & & $1960-1969$ & $50 \%$ \\
\hline \multirow[t]{2}{*}{$51-60$} & $58 \%$ & & & \\
\hline & & & $1970-1979$ & $50 \%$ \\
\hline \multicolumn{3}{|l|}{61 and above } & & \\
\hline \multicolumn{3}{|c|}{ Table 6: Number of Households } & \multicolumn{2}{|c|}{ Table 7:Knowledge of the Iskandar Development } \\
\hline Number of households & Total of Households & Percentage & Know & Do Not Know \\
\hline $1-5$ & 164 & $41 \%$ & $16 \%$ & $84 \%$ \\
\hline $6-9$ & 136 & $34 \%$ & & \\
\hline 10 and Above & 100 & $25 \%$ & & \\
\hline
\end{tabular}

With respect to the number of households, $41 \%$ of the respondents have a household number $1-5$ people, $34 \% 6-9$, and $25 \%$ of households with more than 10 people. One thing that a worry is the $84 \%$ of respondents said they did not know about what was Iskandar Malaysia as compared to respondents who know only $16 \%$.

\section{Component Ranking Quality of Life}

In determining the component priority ranking for the quality of life, a number of components or key indicator was asked to the respondents. This question is important in having feedback from the settlers' perspectives which are the components quality of life according to their preferences. The assessment made by the respondents in Figure 3 shows that the priority is given to component facilities at the highest percentage (31\%), followed by health component $(24.20 \%)$. The next component is education (16.20\%), Followed by social culture $(4.50 \%)$, distribution of income $(5.0 \%)$, public safety $(2.0 \%)$, transport and communication (1.5\%), housing (3.20\%), social participation (2.8\%), life families $(3.0 \%)$, the environment $(5 \%)$ and the last is the environmental component which recorded $1.5 \%$.

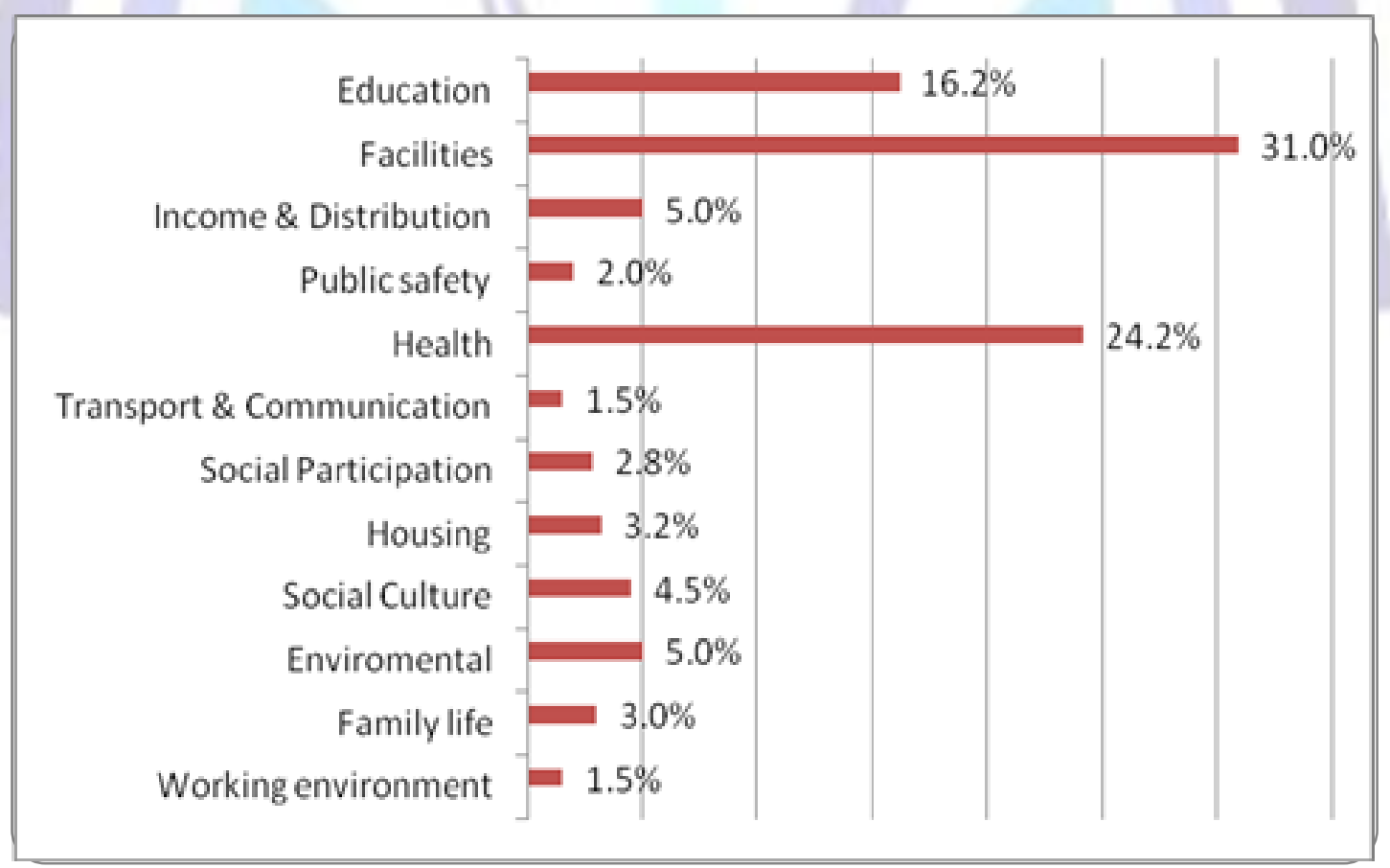

Figure 3: Quality of Life Ranking Components of Population Perspective 


\section{Current Status of Quality of Life Based On Respondent Perspective}

The analysis shows, of the 400 respondents, the feedback showed $47.8 \%$ are very satisfied with the quality of life they have right now and $4 \%$ said they were satisfied. While $30.2 \%$ of respondents expressed their level of quality is moderate and $14 \%$ respondents stated to be in very poor condition and $4 \%$ poor. This is shown in figure 4 .

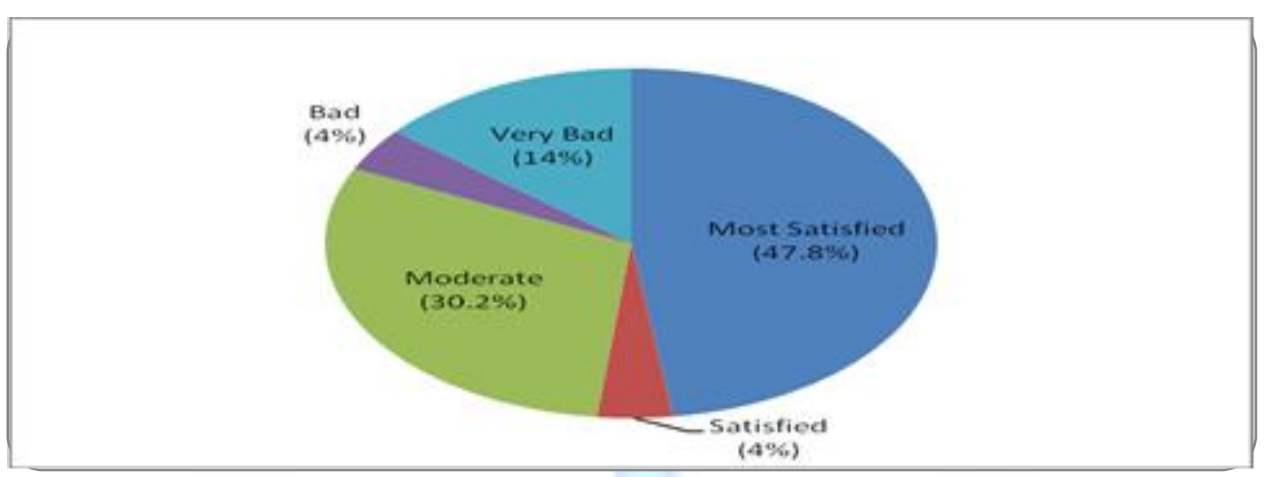

Figure 4: Current Status Quality of Life based on Respondent Perspective

\section{The Measurement of Quality of Life Based on Perceived Quality of Life Index}

The evaluation using 12 components and 66 indicators was conducted to obtain the views of 400 respondents. The findings are assessed using a 1-5 scale adapted from Widjaya (2009). Table 8 shows the scale used where 1 is the most extremely unsatisfied and 5 is the most satisfied.

Table 8: The scale of satisfaction: Perceived Quality of Life Felda Resident in Iskandar Malaysia

\begin{tabular}{|c|c|}
\hline Mean category & Satisfaction Perceived Quality of Life Index \\
\hline $1.00-1.79$ & $\begin{array}{c}\text { Very unsatisfied } \\
\text { \{So do not achieve the requirements and are totally } \\
\text { not satisfied with their quality of life }\}\end{array}$ \\
\hline $1.80-2.59$ & $\begin{array}{c}\text { Unsatisfied } \\
\{\text { Not achieve the requirements and are not satisfied } \\
\text { with their quality of life }\}\end{array}$ \\
\hline $2.60-3.39$ & $\begin{array}{c}\text { Moderate } \\
\{\text { Feel their quality of life are moderate }\}\end{array}$ \\
\hline $3.40-4.19$ & $\begin{array}{c}\text { Satisfied } \\
\begin{array}{c}\text { Achieve requirements and satisfied with their quality } \\
\text { of life }\end{array}\end{array}$ \\
\hline 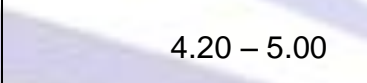 & $\begin{array}{c}\text { Very Satisfied } \\
\{\text { Very satisfied with the quality of their lives }\end{array}$ \\
\hline
\end{tabular}

Source: Adaptation Widjaya, T. (2009)

Table 9 shows the results of the overall assessment of the 12 components and 66 indicators. The analysis showed a total of 10 components of the 12 components are at a moderate level. Only two components are at a satisfactory level of public transportation and housing indicator components.

Table 9: The Results on 66 Indicator Assessment of Quality of Life based on perception index

\begin{tabular}{|c|c|l|c|c|c|}
\hline 1 & Code & Health Component Indicator & Mean & $\begin{array}{c}\text { Mean } \\
\text { Average }\end{array}$ & Remarks \\
\cline { 1 - 3 } & P1 & Overall state health & 2.78 & \multirow{2}{*}{3.13} & \multirow{2}{*}{ Moderate } \\
\cline { 1 - 3 } P2 & Frequency of exercise / healthy activity & 3.10 & \multirow{2}{*}{3.08} & \\
\cline { 1 - 3 } P3 & Avoid the situation of AIDS / HIV & 3.44 & \\
\cline { 1 - 3 } P4 & Hygiene in the home & 3.24 & & \\
\cline { 1 - 3 } & & & \\
\hline
\end{tabular}




\begin{tabular}{|c|c|c|c|c|c|}
\hline \multirow[t]{5}{*}{2} & \multirow[b]{2}{*}{ P6 } & \multicolumn{3}{|l|}{ Environmental Component Indicator } & \multirow{5}{*}{ Moderate } \\
\hline & & Water Quality & \multirow{2}{*}{$\begin{array}{l}3.49 \\
3.07\end{array}$} & \multirow{4}{*}{3.35} & \\
\hline & P7 & Air Quality & & & \\
\hline & P8 & Clean Water Supply & 3.50 & & \\
\hline & P9 & Forested Area & 3.34 & & \\
\hline \multirow[t]{4}{*}{3} & & \multicolumn{4}{|l|}{ Working component indicators } \\
\hline & P10 & Overall condition workplace & 2.42 & \multirow{3}{*}{2.94} & \multirow{3}{*}{ Moderate } \\
\hline & $\mathrm{P} 11$ & Workplace safety & 3.15 & & \\
\hline & P12 & Job Satisfaction & 3.24 & & \\
\hline \multirow[t]{3}{*}{4} & & \multicolumn{4}{|l|}{ Transport Component Indicator } \\
\hline & P13 & Public Transport & 3.36 & \multirow[t]{2}{*}{3.47} & \multirow[t]{2}{*}{ Satisfied } \\
\hline & P14 & Private transport & 3.58 & & \\
\hline \multirow[t]{3}{*}{5} & & \multicolumn{4}{|c|}{ Social Participation component indicators } \\
\hline & P15 & Neighborhood & 3.11 & \multirow[t]{2}{*}{2.92} & \multirow{2}{*}{ Moderate } \\
\hline & P16 & Participation in Social Activities & 2.72 & & \\
\hline \multirow[t]{9}{*}{6} & & \multicolumn{2}{|c|}{ Public Safety Components Indicators } & & \\
\hline & $\mathrm{P} 17$ & Overall security & 3.59 & \multirow{8}{*}{3.36} & \multirow{8}{*}{ Moderate } \\
\hline & P18 & Road Safety for Children & 3.34 & & \\
\hline & P19 & Overall Road Safety & 2.13 & & \\
\hline & P20 & Harassment Drug Addicts & 2.21 & & \\
\hline & P21 & Illegal Immigrants & 2.80 & & \\
\hline & P22 & Residential Area Security & 2.36 & & \\
\hline & P23 & Security Moving In Day & 3.90 & & \\
\hline & P24 & Security Moving at Night & 3.20 & & \\
\hline \multirow[t]{7}{*}{7} & & \multicolumn{2}{|l|}{ Education Component indicators } & & \\
\hline & P25 & Academic Achievement & 2.58 & \multirow{6}{*}{3.34} & \multirow{6}{*}{ Moderate } \\
\hline & P26 & Kids Educational Opportunity & 3.54 & & \\
\hline & P27 & Child Education Affordability & 3.38 & & \\
\hline & P28 & Education Quality & 3.19 & & \\
\hline & P29 & Hang out practice & 3.91 & & \\
\hline & P30 & Disciplinary Violations In Schools & 3.46 & & \\
\hline \multirow[t]{6}{*}{8} & & Housing Component Indicator & & & \\
\hline & P31 & Overall state House & 3.27 & 3.45 & Satisfied \\
\hline & P32 & Adequate Water Supply & 3.34 & & \\
\hline & P33 & Electricity Supply & 3.44 & & \\
\hline & P34 & Sewerage System & 3.22 & $0 . \angle 0$ & Ivivuerate \\
\hline & P35 & Kitchen space & 3.34 & & \\
\hline
\end{tabular}




\begin{tabular}{|c|c|c|c|c|c|}
\hline & P36 & Lounge & 4.11 & & \\
\hline 9 & & Family Component Indicator & & & \\
\hline & P37 & Family Life Assessment & 3.91 & \multirow{7}{*}{3.16} & \multirow{7}{*}{ Moderate } \\
\hline & P38 & Husband and wife relationship \& the Kids & 3.29 & & \\
\hline & P39 & Relationship with Parents & 1.88 & & \\
\hline & P40 & Time Break From Work & 3.94 & & \\
\hline & P41 & Divorce Rate & 4.60 & & \\
\hline & P42 & Kids abuse rate & 1.38 & & \\
\hline & P43 & Baby Abandonment Case & 3.59 & & \\
\hline \multirow[t]{8}{*}{10} & & Component indicators Culture and Leisure & & & \\
\hline & P44 & Frequency of Joint Family Activities & 3.94 & \multirow{7}{*}{2.76} & \multirow{7}{*}{ Moderate } \\
\hline & P45 & Private vacation & 2.75 & & \\
\hline & P46 & Leisure Facilities Adequate & 3.06 & & \\
\hline & P47 & Frequency Go Vacations & 3.75 & & \\
\hline & P48 & Traditional Cultural Performances & 4.60 & & \\
\hline & P49 & Facilities Cultural Activities & 2.08 & & \\
\hline & P50 & Recreational amenities conditions & 1.96 & & \\
\hline \multirow[t]{12}{*}{11} & & Facility Management Component Indicators & & & \\
\hline & P51 & Place of Worship & 2.34 & \multirow{11}{*}{3.23} & \multirow{11}{*}{ Moderate } \\
\hline & P52 & Hospital & 2.32 & & \\
\hline & P53 & Pharmacy / Therapy Center & 1.84 & & \\
\hline & P54 & Postal Service & 3.42 & & \\
\hline & P55 & Police Station & 2.14 & & \\
\hline & P56 & Fire Station & 3.09 & & \\
\hline & P57 & Recreational Place & 3.63 & & \\
\hline & P58 & Public Library & 3.34 & & \\
\hline & P59 & Garbage Collection Services & 3.07 & & \\
\hline & P60 & Petrol Station & 1.96 & & \\
\hline & P61 & Banking Services & 3.26 & & \\
\hline \multirow[t]{6}{*}{12} & & Income Distribution Components Indicators & & & \\
\hline & P62 & Income & 3.26 & \multirow{5}{*}{3.23} & \multirow{5}{*}{ Moderate } \\
\hline & P63 & Employment Opportunities & 2.14 & & \\
\hline & P64 & Business opportunity & 3.39 & & \\
\hline & P65 & Grocery Prices & 3.47 & & \\
\hline & P66 & Shopping Places & 3.91 & & \\
\hline
\end{tabular}




\section{Quality of Life Perceptions Index Iskandar Malaysia}

Next, to get the results of the perception of quality of life index, formula Coombs (1953) has been used. Through this formula the Likert scale is converted to an index.

\begin{tabular}{|c|}
\hline $1-[(x-1) / 4] \times 100$ \\
$X=$ Average Value Mean
\end{tabular}

Through the formula, the Quality of Life Perceptions Index for Felda Residents in Iskandar Malaysia can be calculated and described through Table 10.

Table 10: Perception of Quality of Life Index

\begin{tabular}{|l|c|c|}
\hline Component & Mean Average & $\begin{array}{c}\text { Perception of Quality of Life Index } \\
(100 \%)\end{array}$ \\
\hline Facilities & 2.76 & $56 \%$ \\
\hline Working Environment & 2.94 & $52 \%$ \\
\hline Transport & 3.47 & $38 \%$ \\
\hline Health & 3.13 & $47 \%$ \\
\hline Education & 3.34 & $41 \%$ \\
\hline Housing & 3.45 & $39 \%$ \\
\hline Environment & 3.35 & $41 \%$ \\
\hline Family Life & 3.28 & $43 \%$ \\
\hline Social Participation & 2.92 & $52 \%$ \\
\hline Public Safety & 3.36 & $41 \%$ \\
\hline Culture \& Leisure & 3.16 & $46 \%$ \\
\hline Distribution of Income & 3.23 & $44 \%$ \\
\hline Overall Total Average & 3.20 & $45 \%$ \\
\hline
\end{tabular}

By using the index of perception of quality of life scale in Table 3, the studies revealed that, using perception quality of life index shows, the average for indicator, Felda residents' lives in Iskandar Malaysia stood at $45 \%$ out of $100 \%$. This indicator shows the quality of life the Felda residents are at the moderate level. Detailed indicators for each component specified in Table 10.

\section{CONCLUSION}

The findings of the study showed that the perception of the quality of life in Iskandar Malaysia is at the moderate level. After 5 years of development of the Iskandar Malaysia, local people specifically the Felda residents consider themselves to be at a moderate level of quality of life. Constant efforts by the state government and the federal government as well as the individuals responsible for planning, policy formulation and develop Iskandar Malaysia to consider the appropriate steps in order to enhance the quality of life of the residents and local people in achieving the goals set.

\section{REFERENCES}

[1] Azemi Che Hamid (2006). Persepsi Kualiti Hidup: Satu Tinjauan Ke Atas Penduduk Bandar Seri Kertih, Kemaman, Terengganu. Dinamika Masyarakat Bandar Malaysia Ke Arah Kualiti Hidup Mapan. Penerbitan Universiti Malaya.

[2] Bahagian Penerbitan Dasar Negara. (2010)." Bajet 2011”. Jabatan Penerangan Malaysia.

[3] Bernama (20 Mac 2008). IDR Needs Micro Planning Too.

[4] Bigelow DA, Brodsky G \&. (1982) The concept and measurement of quality of life as a dependent variable in evaluation of mental health services Academic Press New York.

[5] Birnbacher, D. (1999). Quality of Life, Evaluation or Description? Ethical Theory and Moral Practice.

[6] Cummins, R .A. (2005). Moving From the Quality of Life Concept to Theory, Journal of Intellectual Disability Research.

[7] Ferrans, C. E. (1990). Development of a quality of life index for patients with cancer. Oncology Nursing Forum. 
[8] Hancock, T., Labonte, R., Edwards, R. (1999). "Indicators that Count! Measuring Population Health at the ommunity Level." Canadian Journal of Public Health

[9] Haryati Shafii (2010) Tempat Tinggal dan Kualiti Hidup Masyarakat Bandar. Universiti Tun Hussein Onn Malaysia, Batu Pahat, Johor.

[10] Haryati Shafii (2012) Keselesaan Terma Rumah Kediaman dan Pengaruhnya Terhadap Kualiti Hidup Penduduk. Universiti Tun Hussein Onn Malaysia, Batu Pahat, Johor.

[11] Human Development Report. (1999). United Nations Development Programme. Iskandar Region Development Authority (IRDA). (2007). "A World of Investment Opportunities." Johor.

[12] Khazanah Nasional Berhad (2006). "Comprehensive Development Plan of South Johore Economic Region."

[13] Khazanah Nasional Berhad (2006). "Investing In Iskandar."

[14] Laily Paim., Sharifah Azizah Haron., Syuhaily Osman. (2002). Penggunaan Lestari dan Kualiti Hidup. Seminar Kebangsaan Kualiti Hidup Keluarga dan Komuniti Dalam Era Globalisasi, Anjuran Universiti Putra Malaysia.

[15] Lehman, A. F. (1983). "The well-being of chronicmental patients: assessing their quality of life". Archives of general Psychiatry. Apr;40(4):369-73.

[16] Leplege, A. \& Hunt, S. (1997).The problem of quality of life in medicine. JAMA. 1997;278(1):47-50.

[17] Mahadzirah, Sulaiman, Wan Norhayati. (2008). Universiti Malaysia Terengganu Publisher."Quality of Life: Marketing - An Introduction".

[18] National University of Singapore. (2000). "2 $21^{\text {st }}$ Century Quality of Life, Singapore" Proceedings of the Second International Conference on Quality of Life Cities:.

[19] Nik Fuad Nik Mohd Kamil, Noraien Mansor (2007). "Penghidupan Mapan”. Universiti Malaysia Terengganu.

[20] Noll, Heinz-Herbert. (1999). "European System of Social Indicator. EU Reporting", Working Paper 3 Manheim: Centre for Survey Research and Methodology.

[21] Renwick, R. (2006). The quality life model. http://www.utoronto.ca/qol/concepts Search on 0 Sept 2013.

[22] Sen, A.K. (1987). The Standard of Living. Cambridge University Press.

[23] Schmandt, H.J. \& Bloomberg, W. Jr.(1969). The Quality of Urban Life: Urban Affair

[24] Siti Fatimah Abdul Rahman. (2006). Kriteria kualiti hidup berkeluarga. http://www.ikim.gov.my/bm/paparmedia.php?key=781 search on 25 March 2008.

[25] Szalai, A. \& Andrews, F.M. (1980). The Qualiy of life: Comparative studies. USA: Sage a. Studies in International Sociology.

[26] TAC Social Issues Subcommittee. (2004). The Social Component of Community Sustainability: A Framework's User Guide, Greater Vancouver Regional District

[27] Unit Perancang Ekonomi. (1999). "Kualiti Hidup Malaysia 1999”. Jabatan Perdana Menteri, Malaysia

[28] Unit Perancang Ekonomi. (2002). "Kualiti Hidup Malaysia 2002". Jabatan Perdana Menteri, Malaysia

[29] Unit Perancang Ekonomi. (2004). "Kualiti Hidup Malaysia 2004". Jabatan Perdana Menteri, Malaysia

[30] World Health Organization. (1997). Measuring Quality of Life.

[31] Zapf Wolfgang. (1987) Individualisierung und sicherheit. Untersuchungen Zurlebensqualitat in der Bundesrepublik Deutschland. Dalam Aishah Edris, Dan Norbaya Ahmad. (2002). Seminar Kebangsaan Kualiti Hidup Keluarga dan Komuniti Dalam Era Globalisasi, Anjuran Universiti Putra Malaysia.

[32] http://www.physorg.com/news122130432.html, Search on 12 Jan 2013.

\section{Author' biography}

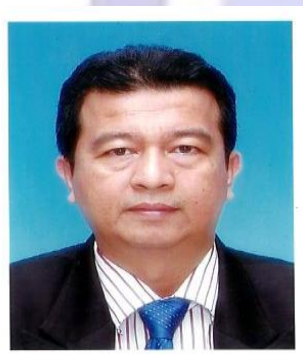

\section{Associate Professor Sr Dr Wan Zahari Wan Yusoff}

Wan Zahari Wan Yusoff is Associate Professor in the Department of Real Estate Management, Faculty of Technology Management and Business, University Tun Hussein Onn Malaysia. Currently, he is a visiting fellow at QUT, Australia. He holds a PhD in Property and Facilities Management, Master Degree in Integrated Construction Project Management, Degree in Estate Management and a Diploma in Valuation.

He has extensive experience in various sectors, including academic and non-academic and in both government and private sector. Among other positions that he had held previously are such as Deputy Director of Facilities and Property Management at UTHM (2009 -2012), Head of Research Centre, Centre of Excellence for Facilities Management, UTHM (2010 - 2012), Head of the Department of Construction Management and Real Estate, UTHM (2008-2010), Research Officer at the National Institute of Valuation (INSPEN, 2000-2003), Valuation Officer at Valuation and Property Services Department, Ministry of Finance, Malaysia (1997-2000), Assistant Valuation Officer (1993 - 1997), Staff on Takaful (M) Sdn. Bhd. (1988-1992) and Assistant Valuer at Property Consultant Company i.e. Azami \& Rahim \& Co. (1986-1987).

He had supervised many students at post graduate level, i.e. Masters and PhD. To date, he has successfully supervised and graduated students at the postgraduate level in research for more than 10. In appreciation to that, he was awarded by the faculty and university as the best supervisor in 2012. He also has produced a number of articles in the Real Estate and Facility Management field and to date he has published more than 20 articles in the international reviewed journals. In the community services, he was active in the areas of volunteerism and appointed as Deputy Commandant which carries the title of Lieutenant Colonel for SISPA - the Civil Defense Students in UTHM. 